\title{
Pruning and fertilization in young Pinus greggii plantations established at Durango, Mexico
}

\author{
Rosales-Serna, Rigoberto; Basave-Villalobos, Erickson *; Ríos-Saucedo, Julio César; \\ Santana-Espinoza, Saúl; Domínguez-Martínez, Pablo Alfredo; Sierra-Zurita Donají \\ 1 Instituto Nacional de Investigaciones Forestales, Agrícolas y Pecuarias. Campo Experimental Valle del \\ Guadiana. Carretera Durango-El Mezquital km 4.5, Durango, Durango, México. C. P. 34170. \\ * Correspondence: basave.erickson@inifap.gob.mx
}

Gitation: Rosales-Serna, R., BasaveVillalobos, E., Ríos-Saucedo, J. C., Santana-Espinoza, S., DomínguezMartínez, P, A., \& Sierra-Zurita D. (2021). Pruning and fertilization in young Pinus greggii plantations established at Durango, Mexico. Agro Productividad. https://doi.org/10.32854 agrop.v14i12.1996

Editor in Chief: Dr. Jorge Cadena Iñiguez

Received: April 13, 2021.

Accepted: November 15, 2021.

Published on-line: December 30, 2021.

Agro Productividad, 14(12). December. 2021. pp: 173-180.

This work is licensed under a Creative Commons Attribution-NonCommercial 4.0 International license.

\begin{abstract}
Objective: To evaluate the effects of pruning and fertilization on the growth of Pinus greggii plantations established at Durango state, Mexico.

Design/methodology/approach: In a plantation (Durango), pruning was applied in three intensities $(0,50$, and $75 \%)$ in a randomized complete block design. Four years later, the basal diameter (Db), normal diameter (ND), total plant height $(\mathrm{PH})$, and stem height $(\mathrm{SH})$ were evaluated. In another plantation (La Soledad), two pruning levels (0 and 50\%) and foliar fertilization (with and without application) were applied in a completely randomized factorial design. Seven months later, $\mathrm{Db}, \mathrm{PH}$, and crown diameter (CD) were assessed. The analysis of their variance and means comparison test (Tukey, $\alpha=0.05)$ were performed.

Results: In Durango, pruning diminished the $\mathrm{Db}$ and PH, but increased the $\mathrm{SH}(\mathrm{p} \leq 0.01)$. In La Soledad, pruning also affected growth. The $\mathrm{Db}, \mathrm{PH}$, and $\mathrm{CD}$ were lower $(\mathrm{p} \leq 0.01)$ when trees were pruned. Fertilization affected the PH $(\mathrm{p} \leq 0.05)$ and $\mathrm{CD}(\mathrm{p} \leq 0.01)$ as well. The $\mathrm{PH}$ and the $\mathrm{CD}$ for both pruned and unpruned trees increased with fertilization.

Limitations/implications: Pruning at 50 and 75\% intensities are not suitable for P. greggii because it reduces their growth.

Findings/conclusions: Fertilization favors the growth of $P$. greggii planted on low fertility soils for both pruned and unpruned trees, but the pruning and fertilization interaction should be examined in detail for a longer period.
\end{abstract}

Keywords: biomass, industry, forest products, productivity, silviculture.

\section{INTRODUCTION}

In Mexico, establishing commercial forest plantations has acquired great relevance during the last decade (Fierros González, 2012). This, as a strategy to increase the productivity of the forest sector and reduce the Mexican national deficit of forest products, which reaches 66\% (Llano \& Fernández, 2017). The state of Durango is part of this strategy and in 2017 it was proposed to establish 1,000 hectares of commercial forest plantations with various species of pine (National Forestry Commission [CONAFOR], 2017), one of them Pinus greggii Engelm. ex Parl. ("pino Prieto"), one of the main species used in this type of production system (Fierros, 2012). Pinus greggii is preferred due to its high growth rate 
coupled with its high potential to establish in limited humidity conditions, which allows it to thrive in marginal sites where other pine species are difficult to establish (Domínguez et al., 2001; Gómez-Romero et al., 2012).

Forest plantations require adequate silvicultural management that increases tree's growth rate because technical shifts are usually long (CONAFOR-Colegio de Postgraduados [CP], 2011). The long period for the plantations profitability onset delay obtaining economic perceptions, which discourages new plantations establishment and limits the continuity in the management of those already established. Therefore, it is a priority to accelerate the growth of commercial $P$. greggii plantations established in marginal agricultural lands, with viable and sustainable silvicultural alternatives, which in turn increase the biomass quantity and quality.

Pruning is a silvicultural practice used in forest plantations to stimulate and regulate the growth of trees, as well as to maintain the shape and density of their crown, ensuring a greater stem height, clean and free of knots (Braz et al., 2017; Ferrere et al., 2015; Ferraz et al., 2016). However, one of the main factors on which its effectiveness depends is the intensity with which it is carried out (Davel, 2013; Erkan et al., 2016). High pruning intensities in young Pinus brutia Ten. plantations (50 and 75\%) decreased tree growth (Erkan et al., 2016). Also, in the plantations of Tectona grandis L. f., pruning of almost 50\% improved growth and production of knot-free wood (Víquez and Pérez, 2005). The effects of pruning are related to its influence on the production/balance rates of endogenous growth regulators, mobilization and redistribution of carbohydrates and nutritional reserves; as well as, with photosynthetic efficiency (Stiles, 1984), all of the physiological processes that can be improved if this silvicultural managing is properly carried out.

Fertilization is another important silvicultural practice in forest plantations management (Smethurst, 2010). Constant availability of nutrients contributes to favorable growth, especially in marginal soils, such as those that predominate the areas where forest plantations of $P$. greggii are established in Durango. In an early fertilization trial, it was reported that fertilization favored P. greggii growth in low-productive sites (Vázquez-Cisneros et al., 2018). The benefits of fertilizing are also reported in a Pinus cooperi C. E. Blanco plantation, in which seedlings improved their growth with the phosphorus application, as this is the most deficient element (Hernández et al., 2018). The above suggests that fertilization can favor the growth of $P$. greggii plantations at Durango. The objective of this research was to evaluate the effect of pruning and foliar fertilization on $P$. greggii growth in plantations established at Durango.

\section{MATERIALS AND METHODS}

\section{Plantation at Durango state}

An experimental agroforestry plantation of $P$. greggii was evaluated in 2020 as a preliminary model of commercial plantations. This plantation was established in 2007 as a provenance test and subsequently treated as a Christmas pine plantation until its management was possible. The plantation had an initial density of 2,222 trees/ha, with 3 $\mathrm{m}$ spacings between rows and $1.5 \mathrm{~m}$ between trees. The experimental site was located at $23^{\circ} 59^{\prime} 27^{\prime} \mathrm{N}, 104^{\circ} 37^{\prime} 30^{\prime} \mathrm{W}$, and an altitude of 1,881 $\mathrm{m}$ a.s.l. The predominant soil in 
the site is loamy (clay and sandy), with intermediate moisture retention capacity, medium depth, 0 to $2 \%$ slope, $7.9 \mathrm{pH}$, and low in organic matter content $(<1.5 \%)$ and nutrients. The climate at the study site is temperate semi-arid $\left[\mathrm{BS}_{1} \mathrm{kw}(\mathrm{w})(\mathrm{e})\right]$, with a rainy season in summer and an annual mean temperature of $16.3^{\circ} \mathrm{C}$. The accumulated rainfall during the year reaches an average of $476 \mathrm{~mm}$, with maximum precipitation between June and September (Medina et al., 2005).

In September 2016, three pruning treatments were applied: 0 (no pruning), 50 and 75\%, under a randomized complete block design with four repetitions and a useful plot of 40 trees (observations) per repetition. Pruning was carried out at the lower part of each tree's crown with appropriate tools (pruning shears and saw) to make clean cuts, close to the trunk and without leaving a stump. Immediately after pruning, the normal diameter (ND) and total plant height $(\mathrm{PH})$ were evaluated, and later in March 2020, the basal diameter (Db), ND, PH, and stem or trunk height ( $\mathrm{SH}$ ) were assessed.

A caliper was used to measure $\mathrm{Db} 10 \mathrm{~cm}$ from the root crown and ND at $130 \mathrm{~cm}$ from uniform stems. The plant and stem height were evaluated with a telescopic metric ruler. The $\mathrm{PH}$ was measured from the soil surface to the main stem apex, the $\mathrm{SH}$ (which is the commercially important part of the stem) from the soil surface at the beginning of the crown. The data obtained were used for the analysis of variance and in the variables that reported significant differences between treatments, based on an $\alpha=0.05$ value, a means comparison test was carried out on them (Tukey; $\mathrm{p} \leq 0.05$ ).

\section{Plantation at La Soledad, Canatlán, Durango.}

A commercial plantation of $P$. greggii established in agricultural soil during 2015 was evaluated. It had a density of 1258 plants/ha (3.00 m between rows and $2.65 \mathrm{~m}$ between plants). In trees with similar height and diameter, two pruning treatments ( 0 and $50 \%)$ and foliar fertilization (without and with application) were applied in 2020. The pruning was carried out on February 23, 2020, just as it was pruned at the Durango, Durango plantation. At 12 and 19 days after pruning, fertilization treatments were applied by spraying foliar fertilizer $\left(\right.$ Bayfolan $\left.^{\circledR}, 1.1 \mathrm{~L} / \mathrm{ha}\right)$, with a manual pump. The soil was a sandy-loam texture, low organic matter content (1.1\%), 14.3\% field capacity, $8.3 \mathrm{pH}$, medium to low levels of nitrogen $(11.1 \mathrm{mg} / \mathrm{kg})$, phosphorus $(18.8 \mathrm{mg} / \mathrm{kg}$ ) and potassium $(582.7 \mathrm{mg} / \mathrm{kg})$. A completely randomized experimental design was used in a factorial arrangement of treatments $(2 \times 2)$ and two repetitions with nine trees each.

The basal diameter $(\mathrm{Db})$ of the stem, total plant height $(\mathrm{PH})$, and crown diameter $(\mathrm{CD})$ were evaluated immediately after pruning and for seven months. For this, nine uniform stems were used per repetition, in which the Db was determined with the caliper at $10 \mathrm{~cm}$ from the soil surface. The PH was determined with a telescopic metric ruler and CD with a tape measure. The PH was evaluated from the soil surface and up to the main stem apex. The CD was measured in two directions (east-west and north-south), to later obtain the mean value used for the analysis of variance. With the obtained data, a statistical analysis was carried out according to the used experimental design. In case of statistical differences (value of $\alpha=0.05$ ), for the main or interaction effects, a means comparison Tukey test $(\mathrm{p} \leq 0.05)$ was done in the SAS software version $9.2^{\circledR}$ (SAS, 2009). 


\section{RESULTS AND DISCUSSION}

At the Durango plantation, the trees did not statistically differ in their ND and $\mathrm{PH}$ values at the time of pruning $(\mathrm{p}>0.05)$. The initial $\mathrm{ND}$ and $\mathrm{PH}$ were $0 \%$ pruning $=6.8 \mathrm{~cm}$ and $4.0 \mathrm{~m} ; 50 \%$ pruning $=6.7 \mathrm{~cm}$ and $3.8 \mathrm{~m} ; 75 \%$ pruning $=7.1 \mathrm{~cm}$ and $4.0 \mathrm{~m}$ respectively. This reference served as the basis for evaluating the effect of pruning treatments on trees with uniform initial growth, and thus, avoiding bias when analyzing the effects in the subsequent evaluation. In 2020, pruning significantly affected (p $\leq 0.01) \mathrm{Db}, \mathrm{PH}$, and $\mathrm{SH}$. The highest $\mathrm{Db}$ was recorded in trees with no pruning $(15.4 \mathrm{~cm})$, this was $9 \%$ higher than the registered value $(14.1 \mathrm{~cm})$ in $50 \%$ of pruned trees (Table 1). Likewise, the $\mathrm{PH}$ was higher in non-pruned trees $(6.8 \mathrm{~m})$ and exceeded by $15 \%$ the $5.9 \mathrm{~m}$ value registered in the $75 \%$ pruning treatment (Table 1). Finally, the SH was 13 times higher in pruning at $75 \%(2.6 \mathrm{~m})$ compared to the lowest $\mathrm{SH}(0.2 \mathrm{~m})$ reported in non-pruned trees (Table 1$)$.

\section{La Soledad, Canatlán, Durango state}

Pruning significantly affected the $\mathrm{Db}, \mathrm{PH}$, and $\mathrm{CD}(\mathrm{p} \leq 0.01)$ variables. Pruning reduced the $\mathrm{Db}$ of the trees by $1.2 \mathrm{~cm}$ when comparing the mean $7.8 \mathrm{~cm}$ value in the treatment with no pruning to the $6.6 \mathrm{~cm}$ of the $50 \%$ pruned trees (Table 2). The $\mathrm{PH}$ had a $25 \%$ superiority in the treatment without pruning $(231.6 \mathrm{~cm})$ in relation to the pruned trees $(185.9 \mathrm{~cm})$ (Table 2). The GD was significantly higher in the treatment with no pruning $(168.1 \mathrm{~cm})$, more than double when compared to the pruned ones $(88.0 \mathrm{~cm})$ (Table 2). Likewise, fertilization statistically affected $\mathrm{PH}$ and $\mathrm{CD}(\mathrm{p} \leq 0.05$ and $\mathrm{p} \leq 0.01$, respectively). Fertilization favored the height growth in both pruned and unpruned trees (Figure 1). The $\mathrm{PH}$ increased $4 \%$ in pruned trees and $25 \%$ in non-pruned trees (Table 2). With fertilization, CD increased $21 \%$ in pruned trees and $13 \%$ in non-pruned trees (Table 2).

Pruning in commercial forest plantations is considered a silvicultural practice that favors tree growth (Erkan et al., 2016; Víquez \& Pérez, 2005) but the results with $P$. greggii do not support this in any of the evaluation sites. None of the analyzed intensities favored growth in height or diameter. Pruning only increased the height of the stems (reduction of the living crown ratio), due to the removal of the basal branches. Similar results were reported in young Pinus brutia plantations, in which 50 and $75 \%$ pruning intensities decreased the growth in the diameter of the trees (Erkan et al., 2016). In a plantation of

Table 1. Average values of the evaluated variables in a Pinus greggii plantation established at Durango, Durango state, Mexico. 2020.

\begin{tabular}{c|c|c|c|c}
\hline Pruning treatment & $\begin{array}{c}\text { Basal diameter } \\
(\mathbf{c m})\end{array}$ & $\begin{array}{c}\text { Normal diameter } \\
(\mathbf{c m})\end{array}$ & Total height $(\mathbf{m})$ & $\begin{array}{c}\text { Trunk height } \\
(\mathbf{m})\end{array}$ \\
\hline $0 \%$ & $15.4^{\mathrm{a}}$ & 9.8 & $6.8^{\mathrm{a}}$ & $0.2^{\mathrm{c}}$ \\
\hline $50 \%$ & $14.1^{\mathrm{b}}$ & 9.3 & $6.1^{\mathrm{ab}}$ & $1.4^{\mathrm{b}}$ \\
\hline $75 \%$ & $15.1^{\mathrm{ab}}$ & 9.6 & $5.9^{\mathrm{b}}$ & $2.6^{\mathrm{a}}$ \\
\hline Average & 14.8 & 9.5 & 6.3 & 1.2 \\
\hline${ }^{\mathrm{l}} \mathrm{CV}(\%)$ & 23.8 & 29.1 & 20.6 & 21.5 \\
\hline
\end{tabular}

${ }^{1} \mathrm{CV}=$ coefficient of variation. Letters in each column represent significant differences between pruning treatments (a-c) (Tukey $\mathrm{p} \leq 0.05)$. 
Table 2. Averages of the evaluated variables at a Pinus greggii plantation with two pruning and fertilization treatments. La Soledad, Durango, Mexico. 2020.

\begin{tabular}{c|l|c|c|c}
\hline \multicolumn{1}{c}{ Treatment } & \multicolumn{1}{|c|}{ Fertilization } & $\begin{array}{c}\text { Basal diameter } \\
(\mathbf{c m})\end{array}$ & $\begin{array}{c}\text { Total height } \\
(\mathbf{c m})\end{array}$ & $\begin{array}{c}\text { Grown diameter } \\
(\mathbf{c m})\end{array}$ \\
\hline \multirow{3}{*}{ With pruning } & Without fertilization & 6.7 & $182.4^{\mathrm{c}}$ & $79.8^{\mathrm{d}}$ \\
\cline { 2 - 5 } & Foliar fertilization & 6.5 & $189.3^{\mathrm{c}}$ & $96.2^{\mathrm{c}}$ \\
\cline { 2 - 5 } & Average & $6.6^{\mathrm{B}}$ & $185.9^{\mathrm{B}}$ & $88.0^{\mathrm{B}}$ \\
\hline \multirow{3}{*}{ Without pruning } & Without fertilization & 7.1 & $205.9^{\mathrm{b}}$ & $157.7^{\mathrm{b}}$ \\
\cline { 2 - 5 } & Foliar fertilization & 8.4 & $257.3^{\mathrm{a}}$ & $178.5^{\mathrm{a}}$ \\
\cline { 2 - 5 } & Average & $7.8^{\mathrm{A}}$ & $231.6^{\mathrm{A}}$ & $168.1^{\mathrm{A}}$ \\
\hline${ }^{\mathrm{l}} \mathrm{CV}(\%)$ & & 23.3 & 22.5 & $22.9^{\mathrm{y}}$ \\
\hline
\end{tabular}

${ }^{1} \mathrm{CV}=$ coefficient of variation. Letters in each column represent significant differences between pruning (AB) and fertilization treatments (a-d) according to Tukey's test $(\mathrm{p} \leq 0.05)$.

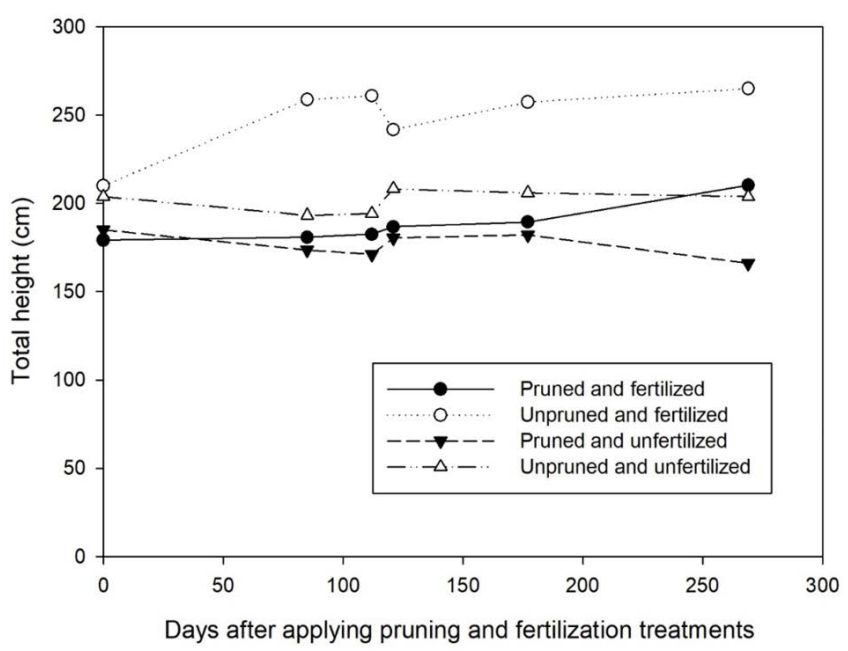

Figure 1. Responses of Pinus greggii trees to treatments of pruning and fertilization in a commercial forest plantation established in La Soledad, Dgo.

Eucalyptus grandis $\times$ Eucalyptus urophylla clones in Brazil, tree growth was also reduced with 40 and $60 \%$ pruning intensities (Ferraz et al., 2016). Yet, in this same plantation, a $20 \%$ pruning intensity improved growth, so that it is deduced that each species has a level at which pruning has favorable and not detrimental effects if properly implemented (Braz et al., 2017). So, the analyzed pruning intensities in $P$. greggii were probably not the most convenient. In $P$. greggii it is suggested to analyze intensities of less than $50 \%$ to define if there is an appropriate level.

In $P$. greggii, pruning is necessary to increase the main stem height, which is the commercial part of the tree, since the species tends to branch almost from the base of the stem, as observed in the unpruned trees of the Durango plantation. Also, pruning has economic implications (Huang \& Kronrad, 2004), therefore, its implementation must be beneficial for tree growth.

In natural stands, natural pruning is a mechanism that favors tree growth by allowing more light to enter the different canopy strata (Musálem \& Fierros, 1996). This happens 
when crown competition is high so that natural pruning can be promoted by maintaining high tree density (Musálem \& Fierros, 1996). Although artificial pruning was used in the assessed plantations, there was no favorable response in the tree's growth due to the influence of the species and other factors such as humidity, nutrients, and planting density that could restrict growth. The density of the plantation was especially high in Durango, compared to the densities recommended for most forest plantations with conifers, close to 1100 trees/ha (CONAFOR-CP, 2011). The pruning effectiveness has been linked to thinning (Ferrere et al., 2015), which is the main silvicultural operation with which the density of the trees is manipulated, both in commercial plantations and natural stands, with repercussions on the growth and wood quality (Ramos et al., 2014; Vásquez-García et al., 2016).

The pruning intensities evaluated in this study were high and ended up damaging the tree's growth rate. Musálem \& Fierros (1996) suggest that the lower branches can be pruned because they contribute little to photosynthesis and tend to present a high expenditure of photosynthate for maintenance. However, it should be considered that in the 50 and $75 \%$ pruning, photosynthetically active tissue was eliminated, which limited photoassimilates production and, therefore, the number of resources for growth. In addition, there may be competition in photoassimilates usage to satisfy other demands, such as defense (Lambers et al., 2008), to heal and cover the stumps left by the branches after pruning. In Pseudotsuga menziesii (Mirb.) Franco, a higher than 25\% pruning severity decreased growth (Davel, 2013). It should also be considered that the evaluated periods could have been insufficient for $P$. greggii to show the positive effects of pruning on its growth since in a study on Pinus nigra Arnold subsp. pallasina, pruning improved growth in height and diameter up to 12 years after its application (Tonguc \& Guner, 2017).

Fertilization is considered an essential silvicultural practice to increase biomass accumulation in forest plantation trees (Smethurst, 2010). Unlike the pruning effect, the results at La Soledad plantation corroborate the importance of trees fertilization to promote their growth (Calixto et al., 2016). Particularly in $P$. greggii, an early fertilization trial confirmed this practice's importance for growth in low-productive areas (VázquezCisneros et al., 2018). The above coincides with the results of this research since the nutrient contribution favored the $P$. greggii plantation performance at La Soledad, which was established in a soil considered marginal due to its physical-chemical characteristics and its agricultural use history.

In other forest species, the nutrient supply in marginal soils has also been favorable to improve product performance. For example, in a Eucalyptus urophylla plantation with boron deficiencies, caused by edaphic acidity and high precipitation at the plantation site, the supply of this nutrient increased the tree's growth and volume (Rodríguez-Juárez et al., 2014).

It is important to highlight the high growth values in trees without pruning due to fertilization. When comparing with pruned trees, it was found that fertilization stimulated growth in the non-pruned ones, because they conserved the nutrients and compounds related to the branches and foliage that are eliminated when pruning. Under natural conditions, foliage loss due to herbivory or another disturbing factor means important 
nutrient loss, which cannot be reabsorbed and retranslocated to other tissues for plant growth (Berendse et al., 2007; Turner, 2004). In Cedrela odorata L., foliage loss caused by the meliaceae borer (Hypsipyla grandella Zeller) generates a nutritional imbalance in the plants which affects their growth, an effect that is partially counteracted by fertilization (Calixto $e t$ al., 2015). This evidence suggests that fertilization in P. greggii offsets the negative effects of pruning on growth, especially in poorly productive areas. This result must be corroborated since during the evaluation period there was no interaction between the studied factors; therefore, it is recommended to examine in detail the interaction between pruning and fertilization over a longer period. These practices are often carried out simultaneously in forest plantations management and their joint effects are rarely examined (Forrester $e t$ al., 2012).

\section{GONGLUSIONS}

Pruning at 50 and 75\% intensities in young high density plantations of $P$. greggii did not favor the growth of the trees in the evaluated study periods. On other hand, fertilization did promote this effect, therefore, it is advisable for it to be done in plantations established on marginal soils. It is recommended to examine other, lower than 50\%, pruning intensities to explore in detail the effects of their interaction with fertilization, since the latter tends to offset the negative effects of pruning at high intensities.

\section{REFERENGES}

Berendse, F. I., de Kroon, H., Braakhekke, W. G. (2007). Acquisition, use, and loss of nutrients. In: F. Pugnaire, F. Valladares (Eds.). Functional Plant Ecology (pp. 259-283). Boca Raton, FL, USA: CRG Press-Taylor \& Francis.

Braz, R. L., Nutto, L., de Matos, J. L. M. (2017). Efeito da poda sobre a qualidade da madeira de Eucalyptus dunnii, Eucalyptus grandis e Eucalyptus saligna. Scientia Forestalis 45 (114), 261-274. Doi: 10.18671/scifor. $\mathrm{v} 45 \mathrm{n} 114.03$

Calixto, G. G., López, M. A., Equihua, A., Lira, D. E., Cetina, V. M. (2015). Crecimiento de Cedrela odorata e incidencia de Hypsipyla grandella en respuesta al manejo nutrimental. Bosque (Valdivia) 36 (2), 265-273. Doi: $10.4067 /$ S07 17-92002015000200012

Comisión Nacional Forestal. (2017). Incrementan 27 por ciento plantaciones forestales en Durango. Disponible en: https://www.gob.mx/conafor/prensa/incrementan-27-por-ciento-plantacionesforestales-en-durango

Comisión Nacional Forestal-Colegio de Postgraduados. (2011). Situación actual y perspectivas de las plantaciones forestales comerciales en México. Zapopan, Jalisco, México: CONAFOR-COLPOS.

Correa R., D., dos Reis, G. G., Reis, M. das G. F., García L., H., Stocks, J. J., de Lima, A. P. L., de Faria, R. S. (2014). Thinning effect on plant growth of pruned eucalypt clone. Revista Árvore 38(3), 495-503. Doi: $10.1590 / \mathrm{S} 0100-67622014000300012$

Davel, M. (2013). Poda en plantaciones de Pseudotsuga menziesii en la Patagonia andina, Argentina. Bosque (Valdivia) 34(2), 13-14.

Domínguez C., P. A., Návar C., J. de J., Loera O., J. A. (2001). Comparación del rendimiento de pinos en la reforestación de sitios marginales en Nuevo León. Madera y Bosques 7 (1), $27-35$.

Erkan, N., Uzun, E., Aydin, A. C., Bas, M. N. (2016). Effect of pruning on diameter growth in Pinus brutia Ten. Plantations in Turkey. Croatian Journal of Forest Engineering 37 (2), 365-373.

Ferraz F., A. G., Mola Y., B., González O., J. R., Scolforo, J. R. S. (2016). Pruning effect in Eucalyptus grandis $\times$ Eucalyptus urophylla clone growth. Scientia Forestalis 44 (111), 729-738. Doi: 10.18671/scifor.v44n111.19

Ferrere, P., Lupi, A. M., Boca, T. (2015). Crecimiento del Pinus radiata sometido a diferentes tratamientos de raleo y poda en el sudeste de la provincia de Buenos Aires, Argentina. Bosque (Valdivia) 36 (3), 423-434. Doi: 10.4067/S0717-92002015000300009.

Fierros G., A. M. (2012). Programa de desarrollo de plantaciones forestales comerciales a 15 años de su creación. Zapopan, Jalisco, México: CONAFOR. 
Forrester, D. I., Collopy, J. J., Beadle, C. L., Baker, T. G. (2012). Interactive effects of simultaneously applied thinning, pruning and fertiliser application treatments on growth, biomass production and crown architecture in a young Eucalyptus nitens plantation. Forest Ecology and Management 267, 104-116. Doi: 10.1016/j.foreco.2011.11.039

Gómez R., M., Soto G., J. C., Blanco G., J. A., Sáenz R., G., Villegas, J., Lindig C., R. (2012). Estudio de especies de pino para restauración de sitios degradados. Agrociencia 46 (8), 795-807.

Hernández V., R. R., López, M. A., Flores N., P. (2018). Crecimiento y estado nutrimental de una plantación de Pinus cooperi Blanco fertilizada con N-P-K. Revista Mexicana de Ciencias Forestales 9 (48), 115-134. Doi: 10.29298/rmcf.v8i48.123.

Huang, C. H., \& Kronrad, G. D. (2004). Economic analysis of pruning and low-density management compared to traditional management of Loblolly Pine plantations in East Texas. Southern Journal of Applied Forestry 28 (1), 12-20. Doi: 10.1093/sjaf/28.1.12

Lambers, H., Chapin, F. S., \& Pons, T. L. (2008). Plant Physiological Ecology. 2nd. Ed.. New York, NY, USA: Springer.

Llano, M., Fernández, H. (2017). Análisis y propuestas para la conservación de la biodiversidad en México 1995-2017. (M. LLano \& H. Fernández, Comps.). Ciudad de México.

Medina G., G., Díaz P., G., López H., J., Ruíz C., J. A., Marín S., M. (2005). Estadísticas climatológicas del estado de Durango (Periodo 1961-2003). Libro Técnico No. 1. SAGARPA-INIFAP-CIRNOC-Campo Experimental Valle del Guadiana. Durango, Dgo., México.

Musálem, M. Á., Fierros, A. M. (1996). Silvicultura de bosques naturales. Apuntes de curso. Chapingo, México: Universidad Autónoma Chapingo.

Rodríguez J., M. I., Velázquez M., A., Gómez G., A., Aldrete, A., Domínguez D., M. (2014). Fertilización con boro en plantaciones de Eucalyptus urophylla S. T. Blake en Tabasco. Revista Chapingo Serie Ciencias Forestales y del Ambiente 20(2), 203-213.

SAS, Institute. (2009). SAS/STAT ${ }^{\circledR}$ 9.2. User's Guide. Cary, NC, USA: SAS Institute Inc.

Smethurst, P. J. (2010). Forest fertilization: Trends in knowledge and practice compared to agriculture. Plant and Soil 335, 83-100.

Stiles, W. C. (1984). Effects of pruning on growth and sizes of trees. Acta Horticulturae 146, 225-230. Doi: 10.17660/ActaHortic. 1984.146.25

Tonguc, F., Guner, S. (2017). Effects of pruning on diameter and height growth of Pinus nigra Arnold subsp. pallasina plantations in Turkey. International Journal of Environment, Agriculture and Biotechnology 2 (1), 248-252. Doi: 10.22161/ijeab/2.1.32

Turner, I. M. (2004). The ecology of trees in the Tropical Rain Forest. (Asthon, P. S., Hubell S. P., Janzen, D. H., Raven, P. H. \& Tomlinson, P. B. Eds.). Cambridge, UK: Cambridge University Press.

Vásquez G., I., López L., M. A., Ángeles P., G., Cetina Á., V. M. (2016). Growth and increase of a Pinus patula plantation with fertilization and thinning treatments. International Journal of Environmental and Agriculture Research 2 (7), 73-78.

Vázquez C., I., Prieto R., J. A., López L., M. A., Wehenkel, C., Domínguez C., P. A., Muñoz S., F. E. (2018). Crecimiento y supervivencia de una plantación de Pinus greggii Engelm. ex Parl. var. greggii bajo diferentes tratamientos de fertilización. Revista Chapingo Serie Ciencias Forestales y del Ambiente 24 (2), 251-264. Doi: 10.5154/r.rchscfa.2017.05.036

Víquez, E., Pérez, D. (2005). Effect of pruning on tree growth, yield, and wood properties of Tectona grandis plantations in Costa Rica. Silva Fennica 39 (3), 381-390. Doi: 10.14214/sf.375

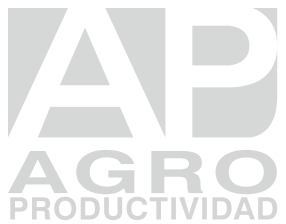

